\title{
Analysis of the organizational cynicism and organizational loyalty: Turkish Police Department Sample
}

\author{
Mehmet Ali Tekiner ${ }^{1}$ \\ Bekir Tavas $^{2}$
}

\begin{abstract}
In the research, it was aimed to evaluate organizational cynicism and organizational loyalty of Turkish Police Department. In the research 153 subjects, all of whom work in the police departments, has been attempted to be analyzed through 5-point Likert scale. The data gathered has been statistically analyzed and the results have been explained.

According to results, it was found that organizational cynicism and organizational loyalty were changed based on demographic properties of participants. Results showed that different demographic properties have different organizational loyalty degree.
\end{abstract}

Keywords: Cynicism; Organizational Loyalty; Police Officers; Behavior; Cognitive.

\section{INTRODUCTION}

In a globalized world, organizations need to take stronger steps so as to survive in competitive environments. Thus, they need to increase the loyalty of their employees to their organizations. The organizations with low loyalty levels are negatively affected and thereby getting negative results. In order to increase organizational loyalty, organizations should provide their employees with rewards, social benefits, promotion opportunities thus enabling them to stay in their organizations and demanding to increase their productivity at work.

Organizations, only when they have set up strong management systems, can longer survive both in competition and business world.

The processes of organizational loyalty are work ethics, communication, trust, respect, participation, sustainability at work, politics and strategy, teamwork, organizational citizenship behaviors and emotions regarding loyalty. In this process, the harmony between organizations and employees are some of the ways leading to success.

Organizations should take some measures to keep their existence. Along with technological changes, organizations may experience such managerial changes as merging, shrinking, and decreasing the member of hierarchical positions, and if badly-managed organizations fail, they might create distrust, doubts and uneasiness among employees and thus organizational cynicism might emerge.

Cynicism, as a term, is making fresh moves towards literature. Disappointment and disillusion among employees towards their organizations may appear. In almost every organization, cynic attitudes among employees could be observed (James, 2005: 6). The most important inputs of organizations are individuals and many factors are influenced by individuals' attitudes, interests, life styles, cultures, belief systems, values, and personal traits. These behaviors prioritize cynicism,

\footnotetext{
1 Assist. Prof. Dr., Police Academy, malitekiner@gmail.com

2 Ph.D., Kars City Police Constabulary, bekirtavas@,hotmail.com
} 
Tekiner, M. A., \& Tavas, B. (2016). Analysis of the organizational cynicism and organizational loyalty: Turkish Police Department Sample. International Journal of Human Sciences, 13(1), 2338-2348. doi:10.14687/ijhs.v13i1.3751

influencing the individual traits of employees and the environment at work. Thus, in the research, it was aimed to evaluate organizational cynicism and organizational loyalty of Turkish Police Department.

\section{THE TERM CYNICISM}

Anderson (1996: 1398) describes cynicism as "general or specific attitude defined by hindrances, despair and disillusion as well as a person, a group, an ideology or negative thoughts and distrust felt towards social traditions or institutions.

Cynics have adopted a life style to prove their aim that they are powerful and distinguished. Diogenes of Sinopi replied the question when asked why he was walking with a lantern during daytime that he was looking for a man of honor (Sheel and Vohra, 2016: 11374-1375; Dean, et al 1998: 342).

According to Kanter and Mirvis (1991: 63), psychological cynicism is the tendency of individuals "to tell a lie, wear fake masks on their faces, be selfish" (Sievers, 2007: 1-3). According to the concept explained, a cynic is a person who does not trust people around, view people as being a liar, an unsociable, amoral and ugly individual. follows;

According to Graham, the personal traits of cynics (Brandes, 1997: 9) can be counted as

-Viewing others as egocentric, liar and indifferent

-Questioning others' motives

-Being cautious in human relations and feeling distrust

-Being hostile and oppressive

-Being repulsive when asked to do something by others

-Being unfriendly and unhelpful

Cynicism is a newly formed concept in a gradually individualistic world. In this ever-evolving concept, individuals protect their own interests and keep these above everything else (Andersson and Bateman, 1997: 449-469).

Organizational cynicism has several meanings, yet the most widely accepted one is that which has been put forward by Dean et al, which could be worded as "negative attitude of individuals towards the organization for which they were hired to work" (Brown and Cregan, 2008: 667-686).

In organizational cynicism, employees display negative and judgmental attitudes towards their organizations, and the underlying reason behind this is that employees observe that they have not benefitted from the rewards equally and justly in their organizations (Abraham, 2000: 269, Anderson and Bateman, 1997: 451).

\section{Reasons for Organizational Cynicism}

There are many reasons for the cynicism in organizations. Badly-managed transition duties, overstress, ambiguity in roles, unmet expectations of individuals and organizations, lacking social life, insufficient say of employees in decision-making process, lack of communication, violation of psychological contracts and dismissal are some examples of the reasons for organizational cynicism (Reichers et al, 1997: 59).

The positive expressions in cynic belief system might be as follows; low potential for leadership, extreme suspicion, high anxiety, introversion and abusive behaviors. Negative thoughts, however, may lead to cynicism along with personal traits like, obsessive disorders and perversion (Özgener et al, 2008: 56).

The most crucial factor in the emergence of organizational cynicism is the violations of psychological contracts. When the informal, interpretable expectations, promises and responsibilities of employees in organizations come to a standstill, this gives rise to disappointments in individuals' perceptions and thus leads to increase in cynical attitudes (Özgener et al, 2008: 57). 
Tekiner, M. A., \& Tavas, B. (2016). Analysis of the organizational cynicism and organizational loyalty: Turkish Police Department Sample. International Journal of Human Sciences, 13(1), 2338-2348. doi:10.14687/ijhs.v13i1.3751

Violation of psychological contract, an emotional symptom of organizational cynicism, leads to the development of emotional conditions inducing distrust of employees towards their employers and demotivation at workplaces (Cartwright and Holmes, 2006: 200, Pugh et al. 2003: 202).

\section{Types of Organizational Cynicism}

Various concepts have been put forward in organizational cynicism and it has been concluded that there are five types of cynicism, which are personality / trait cynicism, social cynicism, vocational cynicism, employee / peer cynicism and (organizational) change cynicism.

\section{Personality Cynicism}

Personality cynicism, as the name suggests, is a type of cynicism, which is innate and is based on the negative perceptions of people. According to personality cynicism, these people look down upon others; underestimate them, treating them disrespectfully and thus leading to weaker ties between people (Abraham, 2000: 270).

Basically, personality cynicism usually focuses on the negative aspects of individuals. The idea here is that these cynics assert that the world is full of selfish people, who are not happy with social interactions, being dishonest and unreal, those tolerating crime, the ones being indifferent to anything. When we look at these reasons, the ones with personality cynicism can be observed to suffer from profound distrust. As a consequence of distrust, these people would frequently display anger in their emotions and behaviours with fury and sorrow. Since personality cynicism is inborn, it is difficult for them to make a change (Abraham, 2000: 271).

When personality cynicism and organizational cynicism are compared, cynicism seems to have originated from individuals, and since organizations are comprised of individuals, it affects organizations as a consequence (Tokgöz and Yllmaz, 2008: 258).

\section{Social Cynicism}

Societies are comprised of individuals and social cynicism is the disillusionment of individuals (Kanter and Mirvis, 1989: 65). When the expectations of individuals are not met, their continual disappointments turn into a social disease. According to some researchers, positive effects of cynicism could be that cynicism could extend dynamism to bring greater effect into larger areas (Cutler, 2000: 266).

\section{Vocational Cynicism}

This is the concept through which individuals display negative and distrusting attitudes towards organizations and authorities (Bateman et al, 1992: 770). Owing to the overload and boredom of work within the embodiment of vocational cynicism, there is a special attitude upon which employees are not rewarded despite the efforts spent (Andersson, 1996: 1397). Simultaneously, there seem to be unwillingness, apathy, and ignorance (Abraham, 2000: 273). In vocational cynicism, when employees display negative attitudes towards their organizations first and then to their social environment and attribute their incompetency to institutions, policies, practices, and shortage of resources, their cynicism may prevail in terms of organizational cynicism (Naus, 2007: 13).

\section{Employee / Peer Cynicism}

This is a concept between employees and employers having emerged as a consequence of fading status differences between decision-makers and practitioners, decrease in the number of executive board members, downsizing in organizations, designating tasks to employees beyond job descriptions, mismanagement, overloaded work schedules, longer working hours (Cartwright and Holmes, 2006: 201). This is both a special and a general attitude which has been shaped via 
Tekiner, M. A., \& Tavas, B. (2016). Analysis of the organizational cynicism and organizational loyalty: Turkish Police Department Sample. International Journal of Human Sciences, 13(1), 2338-2348. doi:10.14687/ijhs.v13i1.3751

disappointment and dispair along with distrust and disdain towards an organization, a social tradition, an ideology, to an individual or a group (Andersson, 1996: 1418).

\section{ORGANIZATIONAL LOYALTY CONCEPT}

Organizational loyalty is a psychological fidelity which employees feel towards their organizations, and this develops through interests felt about workplaces, faithfulness and belief in organizational values (Çekmecelioğlu, 2006: 155; Savage et al, 1997: 79-90).

Becker (1960) explains organizational loyalty as "loyalty to business enterprises is the feeling that if an employee leaves his / her workplace, he/she is afraid that he/she will lose everything and all the things would be futile compared to the efforts, time, labor spent and the status gained if he/she keeps working there".

\section{Factors Affecting Organizational Loyalty}

Loyalty / Continuance is to reach positive results for the organizations by increasing efficiency of employees. For that end, organizations apply innovative entrepreneurships. The factors affecting loyalty are as follows (Çetin, 2004: 99);

i. Age, gender and experience,

ii. Organizational justice, trust and job satisfaction,

iii. Determination of roles or conflict of roles,

iv. Importance of the job carried out, supports offered,

v. Taking place in the decision-making process, being a part of the work,

vi. Job security, recognition, alienation,

vii. Marital status, fringe benefits,

viii. Desperation, working hours, rewards, routineness

ix. Promotion opportunities, wage/salary, other employees,

x. Leadership behaviors, job opportunities outside, interest - respect shown to employees.

\section{The Relationship between Organizational Cynicism and Organizational Loyalty}

Organizational loyalty involves strong belief in continuation of organizational membership and spending efforts during the realization of organizational goals as well as accepting the goals and objectives of the organization and strong affiliation (Vandenberg and Scarpello, 1994: 536, Allen and Meyer, 1990: 2). When the dimensions of organizational loyalty and organizational cynicism are compared, they seem to be totally different from each other (Dean et al., 1998: 348).

Cognitive Dimension: In organizational cynicism, employees assume that there is a deficiency in their integration to the practices of their organization whereas in organizational loyalty, employees may believe that there could be some resemblance between their personal values and goals and those of their organization.

Behavioural Dimension: While organizational cynicism involves the hesitations of employees about whether to leave or stay at work, organizational loyalty covers the intention of employees to continue working at their workplaces.

Affective Dimension: During the experiences of those with organizational cynicism at their organization, these people are observed to be displaying such emotions as underestimation or obstructing while the ones with low level of organizational loyalty may possibly experience deficiency in the loyalty to organization and in feeling proud.

There is an inverse correlation between organizational cynicism and organizational loyalty. As a result of this, organizational cynicism decreases organizational loyalty (Abraham, 2000: 275). 
Tekiner, M. A., \& Tavas, B. (2016). Analysis of the organizational cynicism and organizational loyalty: Turkish Police Department Sample. International Journal of Human Sciences, 13(1), 2338-2348. doi:10.14687/ijhs.v13i1.3751

\section{METHOD}

\section{Aim and Significance of the Research}

The basic aim of the research is to study how organizational cynicism affects organizational loyalty. First of all, while cognitive, affective and behavioral domains / dimensions are analyzed, the effects of demographic variables on these three scales will be taken into account, too.

Within this framework, it is assumed that this study will serve as a resource for the other future studies in this field, putting forward organizational cynicism and loyalty in police departments in Turkey with certain aspects and dimensions to contribute to relevant studies, too.

\section{Research Model and Data Collection Tools}

"The Analysis of the Effect of Organizational Cynicism on Organizational Loyalty: Survey for Police Department Sample" is comprised of four Personal Information Form and 20 survey questions based on the dimensions of organizational justice.

"The Analysis of the Effect of Organizational Cynicism on Organizational Loyalty: Survey for Police Department Sample" have three sub-categories:

The first part of the Questionnaire is based on the Personal Information Form which covers independent variables like "gender", "age", "title" and "terms of office". In the survey, five point Likert scale was employed.

\begin{tabular}{c|c}
\hline $\begin{array}{c}\text { Dimensions of } \\
\text { Organizational } \\
\text { Cynicism and } \\
\text { Organizational Loyalty }\end{array}$ & $\begin{array}{c}\text { Contextual } \\
\text { Variables }\end{array}$ \\
\hline Cognitive & Age \\
\hline Behavioural & Gender \\
\hline Affective & $\begin{array}{c}\text { Title } \\
\text { Terms of Office }\end{array}$ \\
\hline
\end{tabular}

In line with the research model, the hypotheses of the research are as follows;

$\mathbf{H}_{1}$ : Among subjects, there is a significant difference in terms of the Effect of Organizational Cynicism on Organizational Loyalty and Cognitive Dimensions.

$\mathbf{H}_{2}$ : Among subjects, there is a significant difference in terms of the Effect of Organizational Cynicism on Organizational Loyalty and Behavioral Dimensions.

$\mathbf{H}_{3}$ : Among subjects, there is a significant difference in terms of the Effect of Organizational Cynicism on Organizational Loyalty and Affective Dimensions.

As a result of the reliability analysis of the survey, titled, "The Analysis of the Effect of Organizational Cynicism on Organizational Loyalty: Survey for Police Department Sample" Cronbach's Alpha Value was calculated to be $80,4 \%$. Upon the score, it was decided that the survey is reliable.

\section{Population and Sample of the Study}

The population of the study covers all the police officers working in the police departments in Turkey. Within this context, 153 members of the police department in the province of Adana, southern Turkey, were interviewed as the sample group.

\section{Data Analysis}

In the analysis of the data gathered after the survey, "The Analysis of the Effect of Organizational Cynicism on Organizational Loyalty: Survey for Police Department Sample", for the First Chapter: Personal Information, percentage and frequency methods were carried out. In the analysis of data set gathered after the administration of the survey, "The Analysis of the Effect of 
Tekiner, M. A., \& Tavas, B. (2016). Analysis of the organizational cynicism and organizational loyalty: Turkish Police Department Sample. International Journal of Human Sciences, 13(1), 2338-2348. doi:10.14687/ijhs.v13i1.3751

Organizational Cynicism on Organizational Loyalty: Survey for Police Department Sample”, for the Second Chapter: descriptive statistics and hypothesis testing were implemented in analyzing the data set collected, and the data gathered thereunto were evaluated using SPSS 19.0.

\section{RESULTS}

\section{Demographic Features of Participants}

Tablo 1. Frequency Analysis for the Demographic Features of the Subjects

\begin{tabular}{|c|c|c|}
\hline & f & $\%$ \\
\hline \multicolumn{3}{|c|}{ Gender Distribution } \\
\hline Female & 66 & 43.1 \\
\hline Male & 87 & 56.9 \\
\hline \multicolumn{3}{|c|}{ Age Distribution } \\
\hline Less than 30 & 42 & 27.5 \\
\hline $30-35$ & 29 & 19 \\
\hline $36-40$ & 39 & 25.5 \\
\hline $41-50$ & 43 & 28 \\
\hline \multicolumn{3}{|c|}{ Terms of Office } \\
\hline$>4$ Years & 71 & 46.4 \\
\hline 4 Years or less & 82 & 53.6 \\
\hline \multicolumn{3}{|c|}{$\begin{array}{r}\text { Title / Status } \\
\end{array}$} \\
\hline Police Officer & 110 & 60 \\
\hline Sergeant & 20 & 24.9 \\
\hline Inspector & 14 & 9.2 \\
\hline Superintendent & 6 & 5.9 \\
\hline
\end{tabular}

When the demographic characteristics of the subjects were analyzed in terms of gender, we see that $43.1 \%$ of the subjects are female, the rest $56.9 \%$ of them being male. $27.5 \%$ of them are below 30 years of age, $19 \%$ are between 30 and 35, and $25.5 \%$ of them are from 36 to 40 years of age, and finally $28.0 \%$ of them fall into the age group of 41 to 50 . Also, $46.4 \%$ of the police officers stated that they had been working in the police departments for four years and $53.6 \%$ said it was for four or less years in the police department. $60.0 \%$ work as police officers, $24.9 \%$ of them being sergeants and $9.2 \%$ inspectors and $5.9 \%$ of them serve as the superintendents.

The expressions about the "Testing Research Hypotheses in concordance with Cognitive Dimensions" are given in Table 2.

Table 2. The Results for "Testing Research Hypotheses in concordance with Cognitive Dimensions"

H1: Among subjects, there is a significant difference in terms of the Effect of Organizational Cynicism on Organizational Loyalty and Cognitive Dimensions:

\begin{tabular}{|l|l|l|}
\hline $\begin{array}{c}\text { Hypothesis } \\
\#\end{array}$ & \multicolumn{1}{|c|}{ Hypothesis Items } & Sig. \\
\hline $\mathbf{H}_{1 \mathrm{a}}$ & $\begin{array}{l}\text { Between male and female subjects, there is a significant difference in terms of } \\
\text { the Effect of Organizational Cynicism on Organizational Loyalty and } \\
\text { Cognitive Dimensions. }\end{array}$ & 0,08 \\
\hline $\mathbf{H}_{1 \mathrm{~b}}$ & $\begin{array}{l}\text { Among the subjects at different ages, there is a significant difference in terms } \\
\text { of the Effect of Organizational Cynicism on Organizational Loyalty and } \\
\text { Cognitive Dimensions. }\end{array}$ & 0,02 \\
\hline
\end{tabular}


Tekiner, M. A., \& Tavas, B. (2016). Analysis of the organizational cynicism and organizational loyalty: Turkish Police Department Sample. International Journal of Human Sciences, 13(1), 2338-2348. doi:10.14687/ijhs.v13i1.3751

\begin{tabular}{|l|l|l|l|}
\hline $\mathbf{H}_{1 \mathrm{c}}$ & $\begin{array}{l}\text { Among the subjects holding varying titles, there is a significant difference in } \\
\text { terms of the Effect of Organizational Cynicism on Organizational Loyalty } \\
\text { and Cognitive Dimensions. }\end{array}$ & 0,07 \\
\hline $\mathbf{H}_{1 \mathrm{~d}}$ & $\begin{array}{l}\text { Among the subjects with different terms of office, there is a significant } \\
\text { difference in terms of the Effect of Organizational Cynicism on } \\
\text { Organizational Loyalty and Cognitive Dimensions. }\end{array}$ & 0,03 \\
\hline
\end{tabular}

As the $\mathbf{H}_{1 \mathrm{a}}, \mathbf{H}_{1 \mathrm{~b}}$ and $\mathbf{H}_{1 \mathrm{~d}}$ hypotheses of the research are Sig. $\leq 0,05$, it was accepted with the reliability ratio of $\% 95$, whereas the hypotheses of $\mathbf{H}_{1 \mathrm{c}}$ was rejected. In this context, it has been determined that the Effect of Organizational Cynicism on Organizational Loyalty from the point of view of Cognitive Dimensions in the police department sample shows difference depending on the age groups, gender and terms of office, yet it does not display any significant difference in terms of the type of 'title'.

When the differences amongst the variables within the groups are assessed, it is seen that in the Effect of Organizational Cynicism on Organizational Loyalty from the point of view of Cognitive Dimensions, female subjects compared to male subjects, among those whose age are between 36-40 compared to the ones between 41-50, and those with more than four years of service in comparison to those with the terms of office less than four years are more significant (positive). Likewise, the Effect of Organizational Cynicism on Organizational Loyalty from the point of view of Cognitive Dimensions, those in the police departments who serve as sergeants, inspectors and superintendents - compared to common police officers - was determined to be insignificant (negative).

The expressions about the "Testing Research Hypotheses in concordance with Behavioural Dimension" are given in Table 3.

Table 4. The Results for "Testing Research Hypotheses in concordance with Behavioural Dimensions"

H2: Among subjects, there is a significant difference in terms of the Effect of Organizational Cynicism on Organizational Loyalty and Behavioral Dimensions:

\begin{tabular}{|l|l|l|}
\hline $\begin{array}{l}\text { Hypothesis } \\
\text { \# }\end{array}$ & \multicolumn{1}{|c|}{ Hypothesis Items } & Sig. \\
\hline $\mathbf{H}_{2 \mathbf{a}}$ & $\begin{array}{l}\text { Between male and female subjects, there is a significant difference in terms of } \\
\text { the Effect of Organizational Cynicism on Organizational Loyalty and } \\
\text { Behavioral Dimensions. }\end{array}$ & 0,01 \\
\hline $\mathbf{H}_{2 \mathbf{b}}$ & $\begin{array}{l}\text { Among the subjects at different ages, there is a significant difference in terms } \\
\text { of the Effect of Organizational Cynicism on Organizational Loyalty and } \\
\text { Behavioral Dimensions. }\end{array}$ & 0,32 \\
\hline $\mathbf{H}_{2 \mathbf{c}}$ & $\begin{array}{l}\text { Among the subjects holding varying titles, there is a significant difference in } \\
\text { terms of the Effect of Organizational Cynicism on Organizational Loyalty } \\
\text { and Behavioral Dimensions. }\end{array}$ & 0,03 \\
\hline $\mathbf{H}_{2 \mathbf{d}}$ & $\begin{array}{l}\text { Among the subjects with different terms of office, there is a significant } \\
\text { difference in terms of the Effect of Organizational Cynicism on } \\
\text { Organizational Loyalty and Behavioral Dimensions. }\end{array}$ & 0,09 \\
\hline
\end{tabular}

As the $\mathbf{H}_{2 \mathrm{a}}$ and $\mathbf{H}_{2 \mathrm{c}}$ hypotheses of the research are Sig. $\leq 0,05$, it was accepted with the reliability ratio of $\% 95$, whereas the hypotheses of $\mathbf{H}_{2 \mathrm{~b}}$ and $\mathbf{H}_{2 \mathrm{~d}}$ were rejected. In this context, it has been determined that the Effect of Organizational Cynicism on Organizational Loyalty from the point of view of Cognitive Dimensions in the police department sample shows difference depending on the gender and title in the organization, yet it does not display any significant difference in terms of age groups and terms of office. 
Tekiner, M. A., \& Tavas, B. (2016). Analysis of the organizational cynicism and organizational loyalty: Turkish Police Department Sample. International Journal of Human Sciences, 13(1), 2338-2348. doi:10.14687/ijhs.v13i1.3751

When the differences amongst the variables within the groups are assessed, it has been indicated that the Effect of Organizational Cynicism on Organizational Loyalty from the point of view of Behavioral Dimensions, female subjects as opposed to male subjects, those in the police departments who serve as sergeants, inspectors and superintendents - compared to common police officers - are more significant / positive. Nevertheless, among those whose age are below 30 or between 30-35 compared to the ones between 36-40 and those between 41-50 in the police departments and those with the terms of office less than four years in comparison to those with more than four years of service have been found to be more insignificant / negative in their perceptions about Behavioral Dimensions.

The expressions about the "Testing Research Hypotheses in concordance with Affective Dimension" are given in Table 4.

Table 4. The Results for "Testing Research Hypotheses in concordance with Affective Dimensions"

H3: Among subjects, there is a significant difference in terms of the Effect of Organizational Cynicism on Organizational Loyalty and Affective Dimensions:

\begin{tabular}{|l|l|l|}
\hline $\begin{array}{l}\text { Hypothesis } \\
\text { \# }\end{array}$ & \multicolumn{1}{|c|}{ Hypothesis Items } & Sig. \\
\hline $\mathbf{H}_{3 \mathbf{a}}$ & $\begin{array}{l}\text { Between male and female subjects, there is a significant difference in terms of } \\
\text { the Effect of Organizational Cynicism on Organizational Loyalty and } \\
\text { Affective Dimensions. }\end{array}$ & 0,01 \\
\hline $\mathbf{H}_{3 \mathbf{b}}$ & $\begin{array}{l}\text { Among the subjects at different ages, there is a significant difference in terms } \\
\text { of the Effect of Organizational Cynicism on Organizational Loyalty and } \\
\text { Affective Dimensions. }\end{array}$ & 0,09 \\
\hline $\mathbf{H}_{3 \mathbf{c}}$ & $\begin{array}{l}\text { Among the subjects holding varying titles, there is a significant difference in } \\
\text { terms of the Effect of Organizational Cynicism on Organizational Loyalty } \\
\text { and Affective Dimensions. }\end{array}$ & 0,04 \\
\hline $\mathbf{H}_{3 \mathbf{d}}$ & $\begin{array}{l}\text { Among the subjects with different terms of office, there is a significant } \\
\text { difference in terms of the Effect of Organizational Cynicism on } \\
\text { Organizational Loyalty and Affective Dimensions. }\end{array}$ & 0,13 \\
\hline
\end{tabular}

As the $\mathbf{H}_{3 \mathrm{a}}$ and $\mathbf{H}_{3 \mathrm{c}}$ hypotheses of the research are Sig. $\leq 0,05$, it was accepted with the reliability ratio of $\% 95$, whereas the hypotheses of $\mathbf{H}_{3 \mathrm{~b}}$ and $\mathbf{H}_{3 \mathrm{~d}}$ were rejected. In this context, it has been determined that the Effect of Organizational Cynicism on Organizational Loyalty from the point of view of Affective Dimensions in the police department sample shows difference depending on the gender and title in the organization, yet it does not display any significant difference in terms of age groups and terms of office.

When the differences amongst the variables within the groups are assessed, it has been indicated that the Effect of Organizational Cynicism on Organizational Loyalty from the point of view of Affective Dimensions, female subjects as opposed to male subjects, those in the police departments who serve as sergeants, inspectors and superintendents - compared to common police officers - are more significant / positive. Nevertheless, among those whose age are below 30 or between 30-35 compared to the ones between 36-40 and those between 41-50 in the police departments and those with the terms of office less than four years in comparison to those with more than four years of service have been found to be more insignificant / negative in their perceptions about Affective Dimensions.

\section{CONCLUSION AND EVALUATION}

Organizational cynicism is the negative attitudes of individuals with cognitive, affective and behavioral dimensions towards the organizations for which they are hired to work. In literature, the 
Tekiner, M. A., \& Tavas, B. (2016). Analysis of the organizational cynicism and organizational loyalty: Turkish Police Department Sample. International Journal of Human Sciences, 13(1), 2338-2348. doi:10.14687/ijhs.v13i1.3751

effects of organizational cynicism over organizational loyalty have been put forward. Wherever organizational cynicism exists, it is necessary for the organizations to change in a positive way to improve organizational loyalty. As seen from the results of the survey aforementioned, the higher the interests of an individual compared to those of the organization, the higher the organizational loyalty ratio is. Those who are new in the organizations defend organizational cynicism in behavioral dimensions. In cognitive dimension, however, the contradictory data to behavioral dimensions were obtained. What is observed in affective domain is that the ones who are fresh at work - compared to those with longer terms of office - are inclined to have organizational cynicism.

When looking into the p-value scores derived from the first hypothesis, the status variable with the value of 0.074 is rejected and there seems to be no significant difference between the status of the employees at work and the effect of organizational cynicism over organizational loyalty with cognitive dimension.

The personal interests of the officers with better positions at the police departments are prioritized in the decisions taken by the organizations in accordance with the effect of organizational cynicism over organizational loyalty from cognitive dimension point of view. As a result of this, they may prevent the provision of organizational loyalty and lead to the deficiency of certain principles like justice, honesty and sincerity.

Since the p-value scores of some variables like age, gender and terms of office are smaller than 0.05 , the hypotheses have been accepted. In line with these variables, there is a significant difference between the effect of organizational cynicism over organizational loyalty and cognitive dimensions. Employees at younger ages, women and those with terms of office shorter than four years regard the effect of organizational cynicism over organizational loyalty from cognitive dimension perspective as significant (positive).

According to the results of the second hypothesis, when we look at the hypotheses of the employees with shorter terms of office and younger age, the p-value scores are higher than 0.05 and thus the hypotheses have been rejected.

As for the age groups and the titles in their organizations, there is no significant difference between the effects of organizational cynicism over organizational loyalty with behavioral dimensions. The younger employees along with the ones with shorter terms of office, the ones working under the effects of organizational cynicism over organizational loyalty accompanied with behavioral dimensions may have gloomy predictions about future, or might scorn their organizations and criticize harshly. Based on the variables like gender and title at work, hypotheses have been accepted since p-value scores were lower than 0.05 . Depending on the variables like gender and their positions, it is accepted that there is a significant difference between the effects of organizational cynicism over organizational loyalty and behavioral dimensions.

According to the evaluation of the last hypothesis, in such hypotheses where the age and terms of office of the employees were taken into account, p-value is greater than 0.05 and thus hypotheses were rejected.

As for the age groups and the titles in their organizations, there is no significant difference between the effects of organizational cynicism over organizational loyalty with affective dimensions. Among younger employees and officials with shorter work life, the effects of organizational cynicism over organizational loyalty from affective dimension seem to be more visible. These employees have loose loyalty and are deficient in taking pride in their workplaces. Based on the variables related to gender and title at work, hypotheses were accepted since the pvalue is smaller than 0.05 . Depending on gender and positions - as variables - it has been assumed that there is a significant difference between the effects of organizational cynicism over organizational loyalty with affective dimensions. 
Tekiner, M. A., \& Tavas, B. (2016). Analysis of the organizational cynicism and organizational loyalty: Turkish Police Department Sample. International Journal of Human Sciences, 13(1), 2338-2348. doi:10.14687/ijhs.v13i1.3751

\section{BIBLIOGRAPHY}

Abraham, R. (2000). Organizational cynicism: Bases and consequences, Genetic, Social, and General Psychology Monographs,3(126), 269-292.

Allen, N. J. ve Meyer, J. P. (1990), The Measurement and Antecedents of Affective, Continuance and Normative Commitment to the Organization, Journal of Occupational Psychology. 63. ss. $1-18$.

Anderson, L.M. (1996). Employee cynicism: An examination using a Contract violation framework. Human Relations, 49 (11), 1395-1418. Ss

Anderson, L.M., Bateman, T. S. (1997). Cynicism in the workplace: Some causes and effects. Journal of Organizational Behavior, 18, 449-469. ss.

Bateman, T.S., Sakano, T., Fujita, M.(1992). Roger, me, and my attitude: Film propaganda and cynicism toward corporate leadership. Journal of Applied Psychology, 77 (5), 768-771. ss.

Becker, H.S. (1960). "Notes on the Concept of Commitment". American Journal of Sociology, Say1:19, 533-546.

Brandes, P. (1997), Organizational Cynicism: its Nature, Antecedents, and Consequences, Unpublished Doctoral Dissertation, Division of Research and Advanced Studies of the University of Cincinnati, USA.

Brown, M., Gregan, C. (2008). Cynicism: The role of employee involvement. Human Resource Management, 47 (49, 667-686. ss.

Cartwright,S.ve Holmes,N.(2006). The meaning of work: The challenge of regaining employee engagement and reducing cynicism. Human Resource Management Review, 16, 199-208.

Cutler, I. (2000) 'The Cynical Manager', Management Learning, 31(3): 295-312.

Çekmecelioğlu, H. .(2006), "İş Tatmini ve Örgütsel Bağlllık Tutumlarının İşten Ayrılma Niyeti ve Verimlilik Üzerindeki Etkilerinin Değerlendirilmesi: Bir Araştırma”, İş, Güç Endüstri İlişkileri ve İnsan Kaynakları Dergisi, S.2 s.153-168.

Çetin, M.Ö. (2004) Örgüt Kültürü ve Örgütsel Bağllık. Nobel Yayın Dağıtım, Ankara.

Dean Jr, J.W., Brandes, P. ve Dharwadkar, R. (1998). Organizational cynicism. The Academy of Management Review, 2 (23), 341-352

Dean, J., W. JR., Brandes, P., Dharwadkar, R. (1998). Organizational Cynicism. The Academy Of Management Review 23(2) 341-352

Kanter, P.H., Mirvis, D.L.(Spring 1991). Beyond demography: A psychopraphic profile of workforce. Human Resource Management, 30 (1), 45-68. ss.

Naus, A.J.M., (2007). Organizational cynicism on the nature, antecedents, and consequences of employee cynicism toward the employing organization. Unpublished doctoral thesis, Universiteit Maastricht.

Özgener, Ş., Öğüt, A., Kaplan, M. (2008). İşgören-işveren ilişkilerinde yeni bir paradigma: Örgütsel sinizm. M. Özdevecioğlu, H. Karadal (ed.), Örgütsel davranışta seçme konular organizasyonların karanlık yönleri ve verimlilik azaltıcı davranışlar İçinde. Ankara, İlke Yayınevi.

Pugh, S.D., Skarlıck1, D.P., Passell, B.S. (2003). After the fall: Layoff victims's trust and cynicism in re-employment. Journal Occupational and Organizational Psychology, 76, 201-212. ss.

Reichers, A.E., Wanous, J.P., Austın, J.T. (1997). Understanding and managing cynicism about. Academy of Management Executive, 11 (1), 48-59.

Savage, S. P., Moon, G., Kelly, K. \& Bradshaw, Y. (1997). "Divided loyalties?-the police surgeon and criminal justice", Policing and Society, 7:2, 79-98. 

Department Sample. International Journal of Human Sciences, 13(1), 2338-2348. doi:10.14687/ijhs.v13i1.3751

Sheel, R. C. \& Vohra, N. (2016). "Relationship between perceptions of corporate social responsibility and organizational cynicism: the role of employee volunteering", The International Journal of Human Resource Management, 27:13, 1373-1392.

Sievers, B. (2007). "It is new, and it has to be done!': Socio-analytic Thoughts on Betrayal and Cynicism in Organizational Transformation”, Culture and Organization, 13:1, 1-21.

Tokgöz, N., Yılmaz H.,. "Örgütsel Sinizm: Eskiİehir ve Alanya"daki Otel ǴĞletmelerinde Bir Uygulama”, Anadolu Üniversitesi Sosyal Bilimler Dergisi, (2008), 238-305.

Vandenberg, R, J., ve Scarpello V. (1994). "A Longitudinal Asswssment of the Determinant Relationship Between Employee Commitments to the Occupation and the Organization". Journal of Organizational Behavior, Vol:15, 535-547. 